\title{
Sex Education for Muslim Youth and Their Parents
}

Shahid Athar, M.D.

Indianapolis, Indiana

DOI: http://dx.doi.org/10.5915/22-1-13530

\begin{abstract}
Sex education for children and youth is a sensitive but important aspect of their learning. At present, Muslim children are getting secular sex eduction at schools and get the wrong message about sex from the media. In this article the pros and cons of American sex education as related to Islamic concepts of sexuality and marriage are discussed. A curriculum is proposed for Islamic sex eduction to be given at home or Sunday Islamic school.
\end{abstract}

Key words: Sex education, teenage pregnancy, sex in Islam and marriage.

In the name of Allāh, Most Kind, Most Merciful

Allāh says in the Qur'ān:

"Say: Are they equal those who know, and those who do not know?"'

Prophet Muhammad (PBUH) said:

"Blessed are the women of the Ansār (citizens of Medina). Shyness did not stand in their way seeking knowledge about their religion.",

The Qur'ān has given great emphasis on acquiring knowledge. In the days of Prophet Muhammad (PBUH), Muslim men and women were never too shy to ask him questions, including those related to private affairs such as sexual life. Yet, today Muslim parents see sex as a dirty word. They feel uncomfortable in discussing sex with their children, but do not mind the same being taught at their school by secular or non-Muslim teachers (even of the opposite sex), by their peers of either sex, and by the media. An average child is exposed to 9,000 sexual scenes per year on television.

From the Department of Medicine and Endocrinology, Indiana University School of Medicine,

St. Vincent Hospital, Indianapolis, IN.

Reprint requests: 8424 Naab Road, Suite 2N, Indianapolis, Indiana 46260
Parents know that sex is not always a "dirty" word. It is an important aspect of our lives. Allāh, who cares for all aspects of life and not just the way we worship Him, discusses in Qur'ān reproduction, creation, family life, menstruation and even ejaculation. Prophet Muhammad (PBUH), who was sent to us as an example, discussed with his companions many aspects of their sexual life including sexual positions. One reason Muslim parents do not or cannot discuss sex with their children is because of the way they have been brought up: ignorant and perhaps uncomfortable with their own sexuality or its expression. They leave Islamic education to the Sunday school and sex education to the American schools and the media.

\section{What is sex education and who should give it?}

Is sex education about the anatomy and physiology of human body, or about the act of sex, or about reproduction and family life, or about the prevention of sexually transmitted diseases and unwanted pregnancy? Is giving sex education equivalent to giving permission to engage in sex? One sex educator at my son's school told parents, "I am not planning to tell your children whether or not they should engage in sex, or how to do it; but in case they decide to do it, they should know how to prevent sexually transmitted diseases and pregnancy." At present most sex education is incomplete as it does not cover the morality associated with sex, sexual dysfunctions 
and deviations, and the institution of marriage.

One basic question is, do children need sex education? Do you teach a baby duck how to swim or just put it in water and let it swim? After all, for thousands of years men and women had sex without formal education. In many traditional civilizations, sex education starts by trial and error after marriage. Some couples learn faster or better than others, due to difference in sexual perception and expression of one partner. In my opinion, having a dozen children is not necessarily proof of love. An appropriate and healthy sex education is crucial to the fulfillment of a happy marriage.

With regards to the question of who should teach sex education, I believe everyone has a role to play. The parents have to assume a more responsible role. The father has a duty to be able to answer his sons' questions and the mother, her duaghters'. We can rarely influence sex education at school or by the media, but we can supplement it with an ethical and moral dimension and add family love and responsibility. Apart from parents, some roles can be played by Sunday school teachers, the family physicians, the pediatrician and the clergy. Within a family, the older sister has a duty towards the younger one and the elder brother for the younger one.

\section{Sex education in American schools}

In most American schools, public or private, sex education is taught from grades 2 to 12 . The projected 1990 cost to the nation will be $\$ 2$ billion per year.' Teachers are told to give the technical aspects of sex eduction without telling students about moral values or how to make the right decisions. After describing anatomy and physiology of reproduction, the main emphasis is on the prevention of venereal diseases (VDs) and teenage pregnancy. With the rise of AIDS, the focus is on "safe sex", which means having condoms available each time one decides to have sex. With the help of our tax dollars, about 76 schools in the country have started dispensing free condoms and other contraceptives to those who go to school health clinics. Very soon, I project there will be condom vending machine in school hallways.

The role for parents in American sex education is now minimized and sometimes ridiculed. In "Am I Normal," one of the sex education movies I, as a parent at my son's school, was forced to watch, whenever the young boy asks a question about sex, his father shuns him and diverts the topic. Finally, the boy learns about sex from a stranger and then is shown going into a movie theater with his girlfriend.

Secular sex education is devoid of morality. Some views promoted by educators like Dr. Sol Gordon ${ }^{4}$ are unacceptable to our value system. The examples of Dr. Gordon's beliefs are:

a. Nudity in homes (in the shower or the bedroom) is considered to be a good and healthy way to in- troduce sexuality to children under age five, as it gives them an opportunity to ask questions. In the same book he also states that $75 \%$ of all child molestation and incest $(500,000$ per year) occur by a close relative (parent, stepparent, or another family member) in a familiar surrounding.

b. A child's playing with genitals of another child is considered "naive exploration", is permissible and should not be cause for scolding or punishment. ( $\mathrm{He}$ is aware that boys as young as 12 have raped girls as young as 8 . He does not tell us when this "naive exploration"' becomes a sex act.)

c. "Children caught reading 'dirty' magazines should not be made to feel guilty, but parents should use it as a chance to get some useful points across about sexual attitudes, values, and sex exploitation." Like charity, pornography starts at home.

d. "If your daughter or son is already sexually active, instead of telling them to stop it, the parents' moral duty is to protect their health and career by providing them with information and means for contraception and avoiding VD." Educators like Dr. Gordon do not believe that giving sexual information means giving the go ahead signal for sex. It is our wonder why someone, after being told the shape, color, smell, and taste of a new fruit, and the pleasures derived from eating it, would not like to try it. These educators say that even if your child does not ask any questions about sex, parents should initiate the discussion using a neighbor's pregnancy, a pet's behavior, advertisements, popular music or a TV show. I wonder why these educators are obsessed with loading children with sexual information, whether they want it or not.

\section{The more they know it, the more they do it}

Sex education in American schools has not helped decrease the incidence of teenage VD or teenage pregnancy..$^{s-10}$ This is because it has not changed their sexual habits. According to Marion Wright Elderman, president of Children's Defense Fund, in a recent report, "Out of every 20 teens, ten are sexually active but only four use contraception, two get pregnant, and one gives birth." "In 1982, a Johns Hopkins study found one of every five 15 year olds, and one of every three 16 year olds are sexually active. ${ }^{8}$ The incidence increased to $43 \%$ in 17 year olds. A Louis Harris poll in 1986 found that $57 \%$ of the nation's 17 year olds, $46 \%$ of 16 year olds, and $29 \%$ 15 year olds were sexually active. ${ }^{\text {I }}$ It is now estimated that about $80 \%$ of girls entering college have had sexual intercourse at least once. ${ }^{10}$ Going to church does not help either. ${ }^{12}$ Some 1,400 teenagers, mostly white, attending conservative, evangelical churches were sent questionnaires about their sex life. Of these, $26 \%$ of 16 year olds, $35 \%$ of 17 year olds, and 
$43 \%$ of 18 year olds said they had had sexual intercourse at least once. Of those responding, $33 \%$ also said that sex outside of marriage was morally acceptable.

\section{Hazards of early sex.}

The health hazards of early sex include sexual trauma, increase in the incidence of cervical cancer, sexually transmitted disease, and teenage pregnancy.

A variety of injuries are possible when the sexual organs are not sufficiently mature for sex. Some of these injuries have a long lasting effect. ${ }^{13}$ Cervical cancer has been thought to be related to sex occuring at an early age and with multiple partners. Dr. Nelson and his associates, in their article on the epidemiology of cervical cancer, calls this type malignancy a sexually transmitted disease. ${ }^{14}$

One million or more teenage girls become pregnant every year at a rate of 3000 per day. Eighty percent of them are unmarried. Out of this 1 million, about 500,000 decide to keep their baby, 450,000 are aborted, and 100,000 decide to deliver and give the baby up for adoption. In 1950, the incidence of birth from unmarried teenagers was only $13.9 \%$ but in 1985 it had increased to $95 \%$.

It is a myth that teenage pregnancy is a problem of the black or the poor. On the contrary, two thirds of the teenagers getting pregnant are white, suburban, and above the poverty income level. What is life like for those teenagers who experience a pregnancy? Only $50 \%$ complete high school. More than $50 \%$ of them are on welfare. They themselves become child abusers and their children, when grown, have an $82 \%$ incidence of teenage pregnancy. Every year, 8.6 billion dollars are spent for the financial and health care support of these teenage mothers. ${ }^{7,8,10,15}$

The sexual revolution of the 60 's affected another dimension of health care. In 1985 alone, 10 million cases of chlamydia, 2 million of gonorrhea, 1 million of venereal warts, 0.5 million of genital herpes and 90,000 cases of syphilis were diagnosed. ${ }^{16}$ The plague of AIDS is adding a new twist to our fears. ${ }^{17}$ As of August 1989, 100,885 cases have been diagnosed in the USA and $50 \%$ of them have already died. The disease is growing at a rate of one case every 14 minutes, ${ }^{18}$ and so far there is no effective treatment. Father Bruce Ritter in New York, who operates shelters for runaway children, says that the biggest threat to the nation's one million runaways is the threat of AIDS.

There are many reasons why children get involved in sex. ${ }^{19}$ The most common is peer pressure. Their common rationale is that "everybody is doing it." Other reasons are their desire for being considered competent by adults and as a way to get ahead. Another common reason is a lack of self-esteem, which they hope to improve by becoming a father or mother. Sometimes, it is due to a lack of other alter- natives to divert their sexual energies. It can also be due to a lack of love and appreciation at home. Detachment from home can led to attachment elsewhere. The sexual pressure on them is everywhere, at school from their peers, from the TV where about 20,000 sexual scenes are broadcasted annually in advertisements, soap operas, prime time shows, and MTV. Hard core rock music often fans the flames of sexual desire. Most parents do not know what kind of music their children listen to. If they take the time to listen to hard rock, they will know that these songs have pornographic words. This pornographic content made Kandy Stroud, a former rock fan, beg parents to stop their children from listening to what she calls "pornographic rock". ${ }^{20}$

Music may affect mood by activating melatonin, the hormone from the pineal gland in the brain which is turned on by darkness and turned off by flashing light. It is the same gland which has been thought to trigger puberty, and affects the reproductive cycle and sexual mood..$^{21,22}$

\section{What is the true role for parents?}

For their failures (i.e. teenage pregnancy), American educators often put the blame on parents. In fact, in Wisconsin and many other states, the grandparents of a baby born to a teenager are responsible for the financial support of the child. It is important to remember that parents are not consulted should their teenage daughter need contraceptives or an abortion. Faced with such hypocrisy, the parents' job is to instill in their teenager's mind what is not taught in sex education classes, i.e., the reasons not to engage in sex, reasons not to get pregnant, etc. At the same time, adolescents should divert their energies to productive activities like community work, sports, or Sunday schools. Another role for parents is to help their children make decisions. In Islam, anything which leads to wrong is also considered wrong. Consequently, parents should control the music children listen to, the TV programs they watch, the magazines they read, and the dress (which may provoke desire in the opposite sex) they wear. While group social activity should be permitted with supervision, dating should not be allowed. When American teenagers start dating, sex is on their minds.

In fact, $25 \%$ of college freshman boys surveyed said that if on a date they have paid for the dinner and the girl does not "go all the way," they have a right to force her to have sex. Many of these "date rapes" are not reported. Anything which breaks down sexual inhibition and loss of self control, i.e. alcohol, drugs, petting, or for two members of the opposite sex just being together in a secluded place, should not be allowed for Muslim teenagers. Kissing and petting is to prepare the body for sex. The body 
can be brought to a "point of no return."

In summary, Muslim parents should teach their children that they are different than non-Muslims in their value system and their way of life. Having love in your heart for someone of the opposite sex is different than the expression of love through sex. Muslim children should be told that they do not drink alcohol, eat pork, take drugs, and they do not engage in pre-marital sex.

\section{Islamic concept of sexuality}

Islam recognizes the power of sexual need. This subject is discussed in the Qur'an and the sayings of Prophet Muhammad (PBUH) within the context of marriage and family life. ${ }^{12-16}$ Islam does not consider women (or men) to be objects of sexual pleasure except within the framework of a relationship which fulfills the will of God. While sex outside of marriage is a punishable sin, sex with one's spouse is an act of worship. The Islamic laws regarding sex are fixed and do not change with peer pressure or the changing values of society. Virginity at the time of marriage is considered a virtue in Islamic morality but a disadvantage in the West. No wonder less than $10 \%$ of American brides are virgins.

\section{Mention of creation, reproduction, and sex in the} Qur'àn

1. "Did We not create you from a sticky fluid?, Which We laid up in a safe abode, for a known term. Thus We arranged, how excellent is Our arrangement." ${ }^{28}$

2. "So let man consider from what he is created. From a gushing fluid, that issues between the loin and ribs." 29

3. "Verily We created man from a product of wet earth, then placed him as a drop in a safe lodging, then We fashioned the drop a clot, then We fashioned the clot into a little lump, then We fashioned the lump into bones, then We clothed the bones with flesh, and then produced it as another creation. So blessed be Allāh, the best of creators". 30

Commentary: The seminal fluid has all the ingredients (protein, carbohydrate, minerals) that the earth has. The order of embryology given 1,400 years ago when no microscope, $\mathrm{x}$-ray, or ultrasound were available, is the same as discovered now. Western scientists recognized sperm in the 17 th century and thought it to be a miniature pre-formed man. ${ }^{31}$

4. "Your women are a tilth for you, so enjoy your tilth the way you wish, and make an introduction to yourself.", 32

Prophet Muhammad (PBUH) said.

1. "When one of you have sex with his wife it is a rewardable act of charity." The companions were surprised and said, "But we do it purely out of our desire; how can it be counted as a chairty?" The prophet replied, "If you had done it with a forbidden women, it would have been counted as a sin, but if you do it in legitimacy it is counted as a charity.",33

2. "Let not the one of you fall upon his wife like a beast falls. It is more appropriate to send a message afore the act." ${ }^{34}$

3. "Do not divulge secrets of your sex with your wife to another person, nor describe her physical features to anyone.," 35

\section{Concept of adultery (fornication, or zina) in Islam}

Allāh says in the Qur'ān:

1. "Do not come near to adultery. Surely it is a shameful deed and Evil, opening roads to other evils." 36

2. "Say: Verily, my Lord has prohibited the shameful deeds, be it open or secret, sins and trespasses against the truth and reason," ${ }^{37}$

3. "Women impure are for men impure, and men impure are for women impure and women of purity are for men of purity." 38

Prophet Muhammad (PBUH) has spoken in many places of adultery as one of the three major sins. However, the most interesting story is that of a younger man who came to him and asked his permission for fornication, since he could not control himself. The prophet dealt with him with reasoning and asked him if he will approve of someone else having illegal sex with his mother, sister, daughter, or wife. Each time the man said 'no' then the prophet replied that the woman with whom you plan to have sex could also be somebody's mother, sister, daughter, or wife. The man understood and repented. The Prophet prayed for his forgiveness. ${ }^{39}$

Adultery is a crime not against one person but against the whole society. It is a violation of the marital contract. Half of all first time marriages in this country result in divorce within 2 years. The main reason for divorce is extramarital affairs by either the husband or wife. Adultery, which includes both premarital and extramarital sex, is epidemic in this society. Nobody seems to listen to the Bible which says frequently, "Thou shall not commit adultry." The Qur'anic approach, "Do not approach adultery," is more sensible. What it means is that not only illegal sex prohibited, but also anything which leads to illegal sex. These things include dating, free mixing of the sexes, provocative dress, nudity, obscenity, and pornography. The dress code for both men and women is to protect each from temptation and desires by on-lookers who may lose self-control and fall into sin.

Allāh says:

"Say to the believing men, that they should lower their gaze and guard their modesty; that will make for greater purity, and Allāh is well acquainted with 
all they do. And say to the believing women that they should lower their gaze, and guard their modesty . . ." 40

\section{Concept of marriage in Islam}

Islam recognizes the strong sexual urge and desire for reproduction. Thus, Islam encourages marriage as a shield from immorality. In Islam the marriage of a man and woman is not just a financial and legal living arrangement, not even just for reproduction, but provides a total commitment, a contract witnessed by Allāh. Love and joy of companionship are parts of this commitment. A married couple assumes a new social status and responsibility for themselves, their children and their community.

Allāh says:

"Among His signs is that $\mathrm{He}$ created consorts for you from among yourselves, so that you may find tranquility with them, and ( $\mathrm{He}$ ) set love and compassion between you. Verily in this are signs for people who reflect." ${ }^{41}$

Prophet Muhammad (PBUH) said:

1. "Marriage is my tradition. He who rejects my tradition is not of me." 42

2. "Marriage is half of the religion, the other half is being Allāh fearing." "43

In Islam there is no fixed rule for the age of marriage. It is becoming fashionable for young Muslim men not to marry until they have completed their education, have a job, or reached age 26-30 or more. Similarly, young Muslim girls say that they want to marry after age 24 . Why? When asked, they say, "I am not ready for it." Not ready for what? Do they not have normal sexual desires? If the answer is yes then they have only one of the two choices: marry or abstain from sex until they marry.

Allāh says:

"Let those who find not the wherewithal for marriage keep themselves chaste till Allāh finds them the means from His Grace."'44

Prophet Muhammad (PBUH) said:

"Those of you who own the means should marry, otherwise should keep fasting for it curbs desires." 4 s

The western concept for delaying marriage is different than ours. When I suggested this to one of my sexually active young female patients, she bluntly said, "I don't want to sleep with the same guy everynight."

\section{The role of Muslim parents and Muslim organiza- tions}

I am not proposing that all Muslim youth be married at age 16. But I must say that youth should accept the biological instinct and make decisions which will lead to a more satisfied life, devoted to a career rather than spending time chasing (or dreaming about) the opposite sex. Parents should help their sons and daughters in the selection of their mates us- ing Islamic practice as a criterion and not race, color, or wealth. They should encourage them to know each other in a supervised setting.

The community organization has several roles to play:

a) To provide an environment for boys and girls to see and know each other without intimacy.

b) To offer premarital educational courses to boys and girls over 18, and to prepare them for their roles as father and husband or mother and wife.

The father has a special role, mentioned by Prophet Muhammad (PBUH):

"One who is given by Allāh, a child, he should give it a beautiful name, should give him or her education, and training and when he or she attains puberty, he should see to it that he or she is married. If the father does not arrange their marriage after puberty, and the boy or girl is involved in sin, the responsibility of that $\sin$ will lie with the father." 46

\section{The curriculum for Islamic sex education}

Islamic sex education should be taught at home, starting at an early age. Before giving education about anatomy and physiology, the belief in the Creator should be well established. As Dostoevsky put it, "Without God everything is possible,"' meaning that the lack of a belief or awareness of God makes all things permissible. ${ }^{26}$

The father should teach his son and the mother should teach her daughter. In the absence of a willing parent, the next best choice should be a male Muslim teacher (preferably a physician) for boys and a female Muslim teacher (a nurse or physician) for girls, at the Sunday Islamic school.

The curriculum should be tailored according to the age of the child and classes should be separated by sex. Only pertinent answers to a question should be given. For example, if a five year old asks, "How did I get into Mom's tummy?" there is no need to describe the whole act of intercourse. Similarly, it is not necessary to tell a 14 year old how to put on condoms. This might be taught in premarital class just before his or her marriage.

The curriculum for sex education should include:

a) Sexual growth and development

1. Time table for puberty

2. Physical changes during puberty

3. Need for family life

4. Mental, emotional, and social aspects of puberty

b) Physiology of the reproductive system

1. For girls: organs, menstruation, premenstrual syndrome

2. For boys: organs, the sex drive

c) Conception, development of fetus, and birth

d) Sexually transmitted diseases (VD/AIDS): emphasizing the Islamic aspect

e) Social, moral, and religious ethics 
f) How to avoid peer pressure

\section{Sex education after marriage}

This article is not intended to be a sex manual for married couples; however, it is useful to remind the reader of a short verse in the Qur'an:

"They are your garment and you are their garments." ${ }^{4}$ ?

Thus husbands and wives are described as garments to each other. A garment is very close to our body, so they should be close to each other. A garment protects and shields our modesty, so they should do the same for each other. Garments are put on anytime we like, so should they be available to each other anytime. A garment adds to our beauty, so they should praise and beautify each other.

For husbands I should say this: Sex is an expression of love. One without the other is incomplete. Your job is to educate your wife in matters of sexuality especially in your likes and dislikes and not to compare her to other women.

For wives I want to say this: Men's sexual needs are different than women's. Instead of being a passive recipient of sex, try to be an active partner. Your husband is exposed to many temptations outside the home. Be available to please him and do not give him an excuse to make a choice between you and the hellfire.

\section{References}

1. The Glorious Qur'ān, Chapter 39, Verse 9.

2. Sahịh al-Bukhâri: Collection of 'Ahadith, Volume I Book of Knowledge, Page 97, M. M. Khan. ed, No 131 published Dar ul 'Arabiah, Beirut, Lebanon

3. Report On Sex Education. Time Magazine, Noy $24,1986$.

4. Gordon S, Dickman IR: "Sex Education - The Parents Role"; Public Affairs Pamphlet No. 549. Published by Public Affairs Committee, New York, NY.

5. Richard D: Teenage pregnancy and sex education in schools-What works and what does not work. San Antonio Pregnancy Center, 1986, p6.

6. Mast CK: Sex Respect: The Options of True Sexual Freedom. Bradley, Illinois, Respect Inc., 1986, p 41.

7. Zamichow N: Teenage Sex. Ladies Home Journal; Oct 1986, p 138-205.

8. Children Having Children. Time Magazine, Dec 9, 1985.

9. Hatcher A: Solving the teenage pregnancy. Medical Aspects of Human Sexuality, March 1980, p 10-23.

10. What's gone wrong with teen sex. People Magazine, April 13, 1987.

11. Annual Report of Children's Defense Fund. Published in Northside Topics, January, 1988.
12. Report On The Teens Sex Attitude Survey by Eight National Evangelical Churches. Indianapolis Star, Feb. 2, 1988.

13. Elam A, Ray VG: Sexually related trauma - A review. Annals of Emergency Med 1986; 15: 576-584.

14. Nelson CA: A Cancer Journal For Clinicians, Nov/Dec 1984, Published by American Cancer Society.

15. Marvin S: How Adults Could Have Helped Me. Parade Magazine, (Supplement to Indianapolis Star) August 21, 1988, Page 4-7.

16. Time Magazine, February 4, 1985, Page 85.

17. Athar S: The Twentieth Century Plague. Crescent International, Canada, Nov, 1987.

18. Curran J: Report of Center for Disease Control. Indianapolis Star, June 14, 1988.

19. Mast CK: How To Say No To Sex. Medical Aspects Of Human Sexuality, Sept. 1988: 26-32.

20. Stroud: Stop Pornographic Rock. Newsweek Magazine, May 6, 1985.

21. Williams RH: Effects Of Melatonins In Humans. In: Textbook Of Endocrinology, 6th Ed., Page 628.

22. Dracula Of Hormones. Newsweek Magazine; Nov. 25, 1985: 94-95.

23. Bucaille M: The Bible, the Qur'an, and Science. The Holy Scripture Examined in Light of Modern Knowledge. 4th Edition. Publishers Seghers, Paris, France, 1986, pp 207-210.

24. Naqvi MZ: The Modesty and Chastity in Islam. Kuwait, Islamic Book Publisher, pp 28-31.

25. Al Qardawi Y: The Lawful and Prohibited in Islam. Indianapolis: American Trust Publication, 195-197. pp 195-197

26. Hathout H: Islamic Perspective in Obstetrics and Gynecology. The Islamic Organization for Medical Science, 92-122. pp 921-122.

27. Abu Saud M: Sex Roles in Muslim Families of USA. ATP Publication, 1979.

28. The Glorious Qur'ān: Chapter 77, Verses 20-24.

29. The Glorious Qur'ān: Chapter 86, Verses 5-7.

30. The Glorious Qur'ān: Chapter 23, Verse 12-14.

31. Lyons AS, Petrucelli RJ: Medicine - An Illustrated History. Published by Abrams: 432, 1978.

32. The Glorious Qur'ān: Chapter 2, Verse 223.

33. "Muslim" Collection of Ahadith. (quoted in reference No 26, p 96.)

34. "Muslim" Collection of Ahadith. (quoted in reference No 26, p 98.)

35. "Muslim" Collection of Ahadith. (quoted in reference No 26, p 96.)

36. The Glorious Qur'an: Chapter 17, Verse 32.

37. The Glorious Qur'ān: Chapter 7, Verse 33.

38. The Glorious Qur'ān: Chapter 24, Verse 26.

39. Imam Ahmad quoting 'Abu Omama. Modesty And Chastity In Islam. MZ Nadvi, Kuwait, 
Islamic Book Publisher, 30-31. pp 30-31.

40. The Glorious Qur'ān: Chapter 24, Verse 30-31.

41. The Glorios Qur'an: Chapter 30, Verse 21.

42. Sahīh al Bukhāri (reference 2) Book of marriage Vol 7, p2.

43. Collection of Ahādith by Al-Tabarani and Hakim. Quoted in reference No 26, p 141.
44. The Glorious Qur'ān: Chapter 24, Verse 33.

45. Șahịh al-Bukhări (reference No 2). Book of Marriage, Hadith No 3, p 3.

46. Mishkat Al-Masābih. Collection of Ahadith. Publisher, Sheikh Muhammed Ashraf, Lahore, Pakistan, p 271.

47. The Glorious Qur'ān: Chapter 2, Verse 187. 